\title{
Vitamin D and cathelicidin assessment in infection-induced asthma in Egyptian children
}

\author{
Hanan M. Hamed ${ }^{1 *}$, Ayat A. Motawie', Amany M. Abd Al-Aziz ${ }^{1}$, Amal A. Abou El-Ezz², Mona A. M. Awad ${ }^{3}$ \\ and Rasha Nazih Yousef ${ }^{3}$
}

\begin{abstract}
Introduction: Vitamin D deficiency was hypothesized to increase the risk of respiratory infections and asthma exacerbation through a reduced production of cathelicidin, a multifunctional anti-microbial peptide essential for normal immune responses to infections.

Aims: Evaluation of vitamin D status and its impact upon cathelicidin in children with infection-induced asthma through assessment of their serum levels.

Patients and methods: The study included 65 infection-induced asthmatic children aged $9.32 \pm 2.35$ years (33 in exacerbation and 32 severity matched in remission) and 25 healthy controls. All children were subjected to history taking, physical examination, pulmonary function tests, $C B C$, and assessment of serum levels of vitamin $D(25(\mathrm{OH}) \mathrm{D})$ and cathelicidin using ELISA.

Results: All asthmatics and controls were deficient in vitamin $D(\leq 20 \mathrm{ng} / \mathrm{ml})$, and no significant difference was found between controls $(10.77 \pm 5.6 \mathrm{ng} / \mathrm{ml})$, remission group $(9.8 \pm 4.89 \mathrm{ng} / \mathrm{ml})$, and exacerbation group $(8.49 \pm 5$ $\mathrm{ng} / \mathrm{ml}), p=0.29$. Cathelicidin was higher in the control group $(7.69 \pm 4.3 \mathrm{ng} / \mathrm{ml})$ compared to that in the remission ones $(6.88 \pm 3.66 \mathrm{ng} / \mathrm{ml})$, but not significant, while it was significantly higher in the exacerbation group $(9.78 \pm 3.03$ $\mathrm{ng} / \mathrm{ml}$ ) compared to that in the remission ones $(p=0.01)$. No significant difference between the three groups regarding percentage having vitamin D level $<10 \mathrm{ng} / \mathrm{ml}(p=0.3)$. There was no correlation between serum cathelicidin and vitamin D levels in either asthmatics or controls. Both levels had no correlation with spirometry indices and no relation to frequency of exacerbations.
\end{abstract}

Conclusion: Vitamin D deficiency cannot explain infection-induced asthma. Cathelicidin elevation in exacerbations seems to be independent of vitamin D.

Keywords: Vitamin D, Cathelicidin, Infection-induced asthma

\section{Introduction}

Bronchial asthma is considered one of the most common chronic diseases, and it affects about 300 million people all over the world (Global Strategy for Asthma Management and Prevention 2011). A significant number of asthmatic patients are at increased risk of asthma-related mortality and severe exacerbations; the intense rise in childhood asthma prevalence in recent

\footnotetext{
* Correspondence: hmhamed63@yahoo.com

${ }^{1}$ Pediatric Department, National Research Centre, Cairo, Egypt

Full list of author information is available at the end of the article
}

decades in most countries is due to important environmental determinants affecting a genetically susceptible population (gene-environment interaction) (Braman 2006). Vitamin D is thought to be one of the environmental factors that increase the pattern of asthma, and many inconsistent results are raised (Adams and Hewison 2008). It may act through enhancing Th2 responses and inhibiting Th1 (Jirapongsananuruk et al. 2000), while inhibition of both Th2 and Th1 responses was proved by others (Urry et al. 2009). Due to its effects on adaptive and innate immunity, vitamin $\mathrm{D}$ was linked to 
host-defensive mechanisms against respiratory tract pathogens (Bener et al. 2012).

It also has a role in Toll-like receptor signaling due to infections by increasing the production of antimicrobial peptides as cathelicidin (Prentice 2008).

During bacterial infection, circulating 25 vitamin $\mathrm{D}$ is converted to $1,25(\mathrm{OH})$ vitamin $\mathrm{D}$ by macrophages; this is a direct stimulant of the expression of genes encoding for many antimicrobial peptides (mainly cathelicidin) (White 2010).

Children with vitamin D deficiency have been shown to be at higher risk of respiratory infections, which is the main stimulant of asthma exacerbation (Paul et al. 2012). However, the exact role of vitamin D in bronchial asthma is still not clearly determined (Mak and Hanania 2011; Miraglia del Giudice and Allegorico 2016).

\section{Aim}

The aim of this study was to assess vitamin D status and its impact upon cathelicidin anti-microbial peptide in children with infection-induced asthma through detection of their levels in serum.

\section{Patients and methods}

A cross-sectional, case-control study was designed, it included 65 asthmatic children aged 6-14 years attending Allergy Clinic, Abo Rish Hospital-Cairo University and Allergy Clinic, National Research Centre in the period between November 2015 and February 2016. All of them were chronic asthmatics according to GINA guidelines, 2011 (Global Strategy for Asthma Management and Prevention 2011). Exclusion criteria were parasitic infestations, autoimmune diseases, T.B., skeletal manifestations of vitamin $\mathrm{D}$ deficiency, chronic diseases that can affect the level of serum vitamin D (renal diseases, inflammatory bowel disease), children receiving vitamin D supplementation, or any drug (calcium, calcitonin, anticonvulsant) affecting its level during the last 6 months. We classified asthmatics patients into 33 patients in infection-induced exacerbation by symptoms of upper respiratory infection (URTI) and clinical examination and 32 patients in remission and 32 patients in remission. Criteria for clinical URTI were defined as two or more of the following symptom: fever, cough, headache, sneezing, runny nose and nasal congestion, pharyngeal hyperemia, and sore throat. The subgroups of asthmatic patients were severity matched in the last 3 months. Twenty-five normal healthy children of the same age and sex were included as a control group. Informed written consents were taken from all guardians of children. The study was approved by the ethical committee of the National Research Centre. All subjects were subjected to full history taking using the allergy sheet including personal history, history of upper respiratory symptoms, precipitating factors, asthma attacks (duration of asthma, frequency, and severity of attacks), protocol of asthma management and prevention, presence of systemic illness, vitamin D supplementation/ any medication, and family history of asthma. Exposure to sunlight and its average duration in hours/day during the last month was recorded. Clinical examination with anthropometric measures (height, weight, and BMI) was calculated. Pulmonary function tests using a spirometer (Fukuda Denshi, Spirosift SP5000) were assessed. Laboratory investigations were assessed as follows: $5 \mathrm{ml}$ peripheral venous blood was withdrawn from every patient and control subject under complete aseptic conditions, $1 \mathrm{ml}$ was anticoagulated with EDTA tube for CBC, and the rest was centrifuged, aliquoted, and stored at $20{ }^{\circ} \mathrm{C}$ for assessment of both serum vitamin $\mathrm{D}$ and cathelicidin antimicrobial peptide. Serum 25-hydroxy vitamin $\mathrm{D}$ levels were measured using a commercial enzyme-linked immunosorbent assay (ELISA) kit developed by Bioassay Technology Laboratory. Shanghai, China, catalog number EA1981 Hu. 25(OH)D is considered the best circulating biomarker of vitamin $\mathrm{D}$ status because it has longer half-life (2-3 weeks) than 1,25(OH)D (4h) (Holick 2009). The normal range for 25 -hydroxy vitamin D is $30-60 \mathrm{ng} / \mathrm{ml}$. Insufficiency was diagnosed at level $<30 \mathrm{ng} / \mathrm{ml}$, deficiency at level $<20 \mathrm{ng} /$ $\mathrm{ml}$ and severe deficiency at level $<10 \mathrm{ng} / \mathrm{ml}$ (Holick 2007). Human cathelicidin antimicrobial peptide (CAMP) were measured using solid-phase enzyme-linked immunosorbent assay (ELISA), catalog number MBS013541. My Bio Source, Inc. P.O. Box 153308, San Diego, CA, 92195-3308, USA.

\section{Statistical analysis}

Data were analyzed using the statistical package version 15 (SPSS Inc., Chicago, IL, USA). Numerical data were expressed as mean and standard deviation. Qualitative data were expressed as frequency and percentage. The chi-square test (Fisher exact or chi-square test) as indicated were used to examine the relationship between qualitative variables. For quantitative data, the comparison between two groups was done using the Student $t$ test. One-way ANOVA test was used to compare three or more independent means followed by post hoc test when there was a significance. Pearson correlation coefficient was used to examine the relationship between two quantitative variables. $p$ value $\leq 0.05$ was considered significant.

\section{Results}

The demographic data of the patients group was presented in Table 1. Mean age was $9.32 \pm 2.35$ years (31 males and 34 females). 
Table 1 Demographic and clinical data of the asthmatic patients $(n=65)$

\begin{tabular}{llc}
\hline Variable & Mean \pm SD & Number/frequency (\%) \\
\hline Age (years) & $9.32 \pm 2.35$ & $31 / 34$ \\
Sex (males/females) & $(7.27 \pm 1.9)$ & \\
Duration of disease (years) & $(2.4 \pm 0.64)$ & $50(78.1 \%)$ \\
Frequency of attacks/month & & $10(11.4 \%)$ \\
Positive family history & & $65(100 \%)$ \\
Positive parenteral consanguinity & & $17(26.6 \%)$ \\
Fever/rhinitis before asthma & & $(46.4 \pm 45.6)$ \\
Associated allergic disease & & \\
Duration of exposure to sun (min/day) & & \\
\hline
\end{tabular}

The comparative data between patient's subgroups and control group were presented in Table 2 and there was a significant elevation regarding WBCs between patients (remission/exacerbation) compared to control. The absolute eosinophilic count was significantly elevated in patients with exacerbation compared to controls. All our studied groups were deficient in vitamin $\mathrm{D}(\leq 20 \mathrm{ng} / \mathrm{ml})$, Fig. 1. Vitamin D was reduced in patients (both groups) compared to controls but not significant, cathelicidin was higher in control group than remission group but not significant, while it was significantly higher in the exacerbation group compared to remission ones $(p=$ 0.01) (Fig. 1).

Comparing the percentage of children having vitamin D level $<10 \mathrm{ng} / \mathrm{ml}$ within each group revealed no significant difference between the three groups (Fig. 2).

Vitamin D and serum cathelicidin had no correlation with duration of the disease, absolute eosinophil counts, or spirometry indices apart from positive correlation between PEFR (\% of predicted) and vitamin D (Table 3). There was no correlation between serum cathelicidin and vitamin D levels in either asthmatics $(r=-0.06$ and $p=0.64)$ or in controls $(r=.187, p=.418)$, also no correlation between both levels in either exacerbation or remission $(p=0.7$ and $r=0.07 ; p=0.4, \quad r=0.1)$ respectively. There was no correlation between BMI and cathelicidin $(r=0.24, p=0.08)$.

Daily exposure to sun $>30$ min significantly increased the level of vitamin $\mathrm{D}$ in the studied patients (exposed $(10.16 \pm 5.03 \mathrm{ng} / \mathrm{ml})$ vs non-exposed $(7.65 \pm 4.65 \mathrm{ng} / \mathrm{ml})$, $p=0.05$. No difference between males and females was found regarding vitamin D or serum cathelicidin levels.

\section{Discussion}

Vitamin D deficiency has been recorded in many countries worldwide, even in those with excessive sun

Table 2 Comparison between asthmatics and control regarding demographic and laboratory data

\begin{tabular}{|c|c|c|c|c|}
\hline Variable & $\begin{array}{l}\text { Healthy control } \\
\text { (group 1) }\end{array}$ & $\begin{array}{l}\text { Patients in remission } \\
\text { (group 2) }\end{array}$ & $\begin{array}{l}\text { Patients in excerption } \\
\text { (group 3) }\end{array}$ & $\begin{array}{l}p \text { value } \\
\text { (between groups) }\end{array}$ \\
\hline Age & $8.8 \pm 2.2$ & $9.3 \pm 2.4$ & $9.2 \pm 2.3$ & 0.7 \\
\hline Sex males/females & $15 / 20$ & $19 / 13$ & $21 / 11$ & 0.8 \\
\hline Weight (kg) & $31.2 \pm 11.1$ & $30.6 \pm 9.6$ & $31.9 \pm 12.7$ & 0.9 \\
\hline Height (cm) & $130.7 \pm 11.2$ & $125.7 \pm 9.8$ & $129.2 \pm 9.7$ & 0.2 \\
\hline $\mathrm{BMI}\left(\mathrm{kg} / \mathrm{m}^{2)}\right.$ & $17.7 \pm 3.4$ & $19.2 \pm 5$ & $18.5 \pm 4.9$ & 0.5 \\
\hline $\mathrm{HB}(\mathrm{gm} / \mathrm{dl})$ & $12.9 \pm 1.6$ & $12.7 \pm 1.02$ & $12.6 \pm 0.9$ & 0.9 \\
\hline $\mathrm{RBCs}\left(\right.$ cells $/ \mathrm{mm}^{3}$ ) & 4.70 & 4.76 & 4.73 & 0.63 \\
\hline WBCs (cells $/ \mathrm{mm}^{3}$ ) & $5.8 \pm 1.5$ & $\begin{array}{l}7.5 \pm 2.5^{*} \\
(p=0.03)\end{array}$ & $\begin{array}{l}8.9 \pm 4.2^{* *} \\
(p=0.001)\end{array}$ & 0.001 \\
\hline AEC (cells/mm $\left.\mathrm{mm}^{3}\right)$ & $207.8 \pm 119.1$ & $340.1 \pm 312.3$ & $\begin{array}{l}389.7 \pm 347^{* *} \\
(p=0.01)\end{array}$ & 0.04 \\
\hline Vitamin D (ng/ml) & $10.77 \pm 5.6$ & $9.8 \pm 4.89$ & $8.49 \pm 5$ & 0.29 \\
\hline Serum cathelicidin (ng/ml) & $7.69 \pm 4.3$ & $6.88 \pm 3.66$ & $\begin{array}{l}9.78 \pm 3.03^{* * *} \\
(p=0.01)\end{array}$ & 0.03 \\
\hline
\end{tabular}

$B M I$ body mass index, $A E C$ absolute eosinophilic count

${ }^{*}$ Comparing healthy controls with patients in remission (groups 1 and 2)

**Comparing healthy controls with patients in exacerbation (groups 1 and 3)

${ }^{* * *}$ Comparing patients in remission with patients in exacerbation (groups 2 and 3 ) 


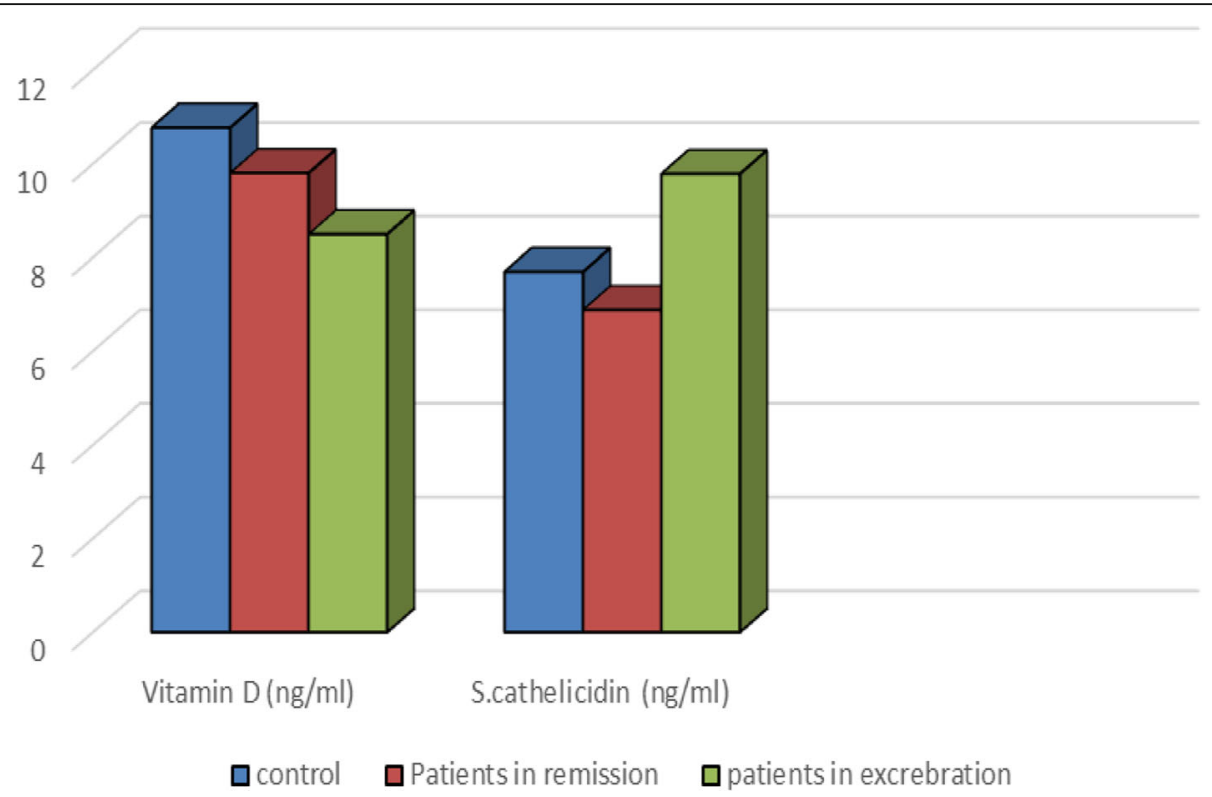

Fig. 1 Serum vitamin D and cathelicidin levels in the three studied groups

exposure (Brehm et al. 2009). The demonstration of the role of vitamin $\mathrm{D}$ in regulation of immune response and the parallel epidemiological pattern between vitamin $\mathrm{D}$ deficiency and asthma has led to the hypothesis that there is causal relationship between vitamin D and allergic respiratory diseases (Litonjua and Weiss 2007; Freishtat et al. 2010; Comberaiti et al. 2014).

In our study, vitamin $\mathrm{D}$ deficiency $(<20 \mathrm{ng} / \mathrm{ml})$ was found in all the studied groups (asthmatics and controls), also the level was found to be $<10 \mathrm{ng} / \mathrm{ml}$ in $62.4 \%, 54.5 \%$, and $52 \%$ of patients in remission, exacerbation, and healthy controls respectively.
Our results regarding vitamin D deficiency in controls agreed with many studies, an Indian one reported $25(\mathrm{OH}) \mathrm{D}$ level below $20 \mathrm{ng} / \mathrm{ml}$ in $62-82 \%$ of children (Harinarayan et al. 2008). The National Health and $\mathrm{Nu}-$ trition Examination Survey (NHANES) 2001-2004, reported that $61 \%$ of US children had level between 15 and $29 \mathrm{ng} / \mathrm{ml}$, while $9 \%$ had level below $15 \mathrm{ng} / \mathrm{ml} 19$. $33.3 \%$ of healthy Egyptian children $6-16$ years and $37.5 \%$ aged 2-18 years have insufficient vitamin $\mathrm{D}$ in spite of being a sunny country (Hamed et al. 2016; El-Menem et al. 2013). FAO/WHO Expert Consultation (2004), recorded that about $30 \mathrm{~min}$ of skin exposure (without sunscreen) of the face and arms to sunlight can supply all

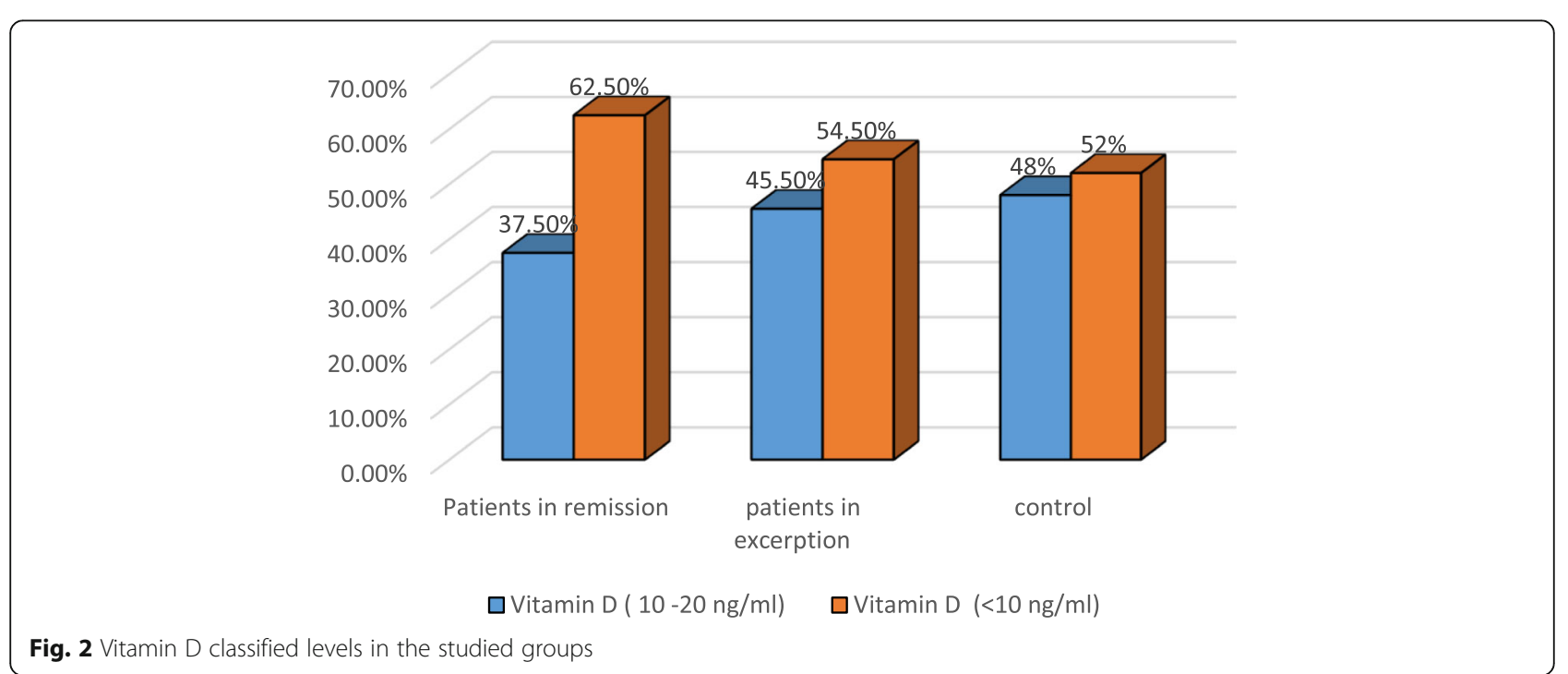


Table 3 Vitamin D and cathelicidin correlations with different spirometry indices in asthmatics

\begin{tabular}{llll}
\hline Variant & & Vitamin D $(\mathrm{ng} / \mathrm{ml})$ & Cathelicidin $(\mathrm{ng} / \mathrm{ml})$ \\
\hline FVC \% of predicted & $r$ & 0.119 & -0.032 \\
& $p$ & 0.484 & 0.85 \\
FVE1\% of predicted & $r$ & 0.095 & 0.013 \\
& $p$ & 0.576 & 0.938 \\
FEV1/FVC\% & $r$ & 0.223 & 0.048 \\
PEFR \% of predicted & $p$ & 0.219 & 0.796 \\
& $r$ & 0.348 & -0.008 \\
FEF 25-75\% of predicted & $p$ & 0.035 & 0.961 \\
& $p$ & 0.466 & 0.199 \\
\hline
\end{tabular}

FVC forced vital capacity; FEV1 forced expiratory volume during first second; PEFR peak expiratory flow rate

the daily body requirements of vitamin D (FAO/WHO Expert Consultation 2004). In our study, daily exposure to sun $30 \mathrm{~min}$, significantly increased vitamin D level in our patients; however, both groups are deficient in vitamin D. Duration of sun exposure was stated to be one of the risk factors of vitamin D deficiency (Arikoglu et al. 2015).The air pollution in our country may play a role in the prevention of ultraviolet rays from reaching the skin. No significant difference was found between males and females excluding the effect of clothing habits.

Vitamin D was reduced in our asthmatics compared to controls but was statistically insignificant. Our result agreed with many studies who found no significant difference between asthmatics and control regarding vitamin D insufficiency and deficiency (Braman 2006; Hamed et al. 2016; Soheila et al. 2011). Others found higher incidence of vitamin D deficiency among asthmatics compared to non-asthmatics (El-Menem et al. 2013; Arikoglu et al. 2015; Kolokotroni et al. 2015; Uysalol et al. 2013) and to controlled asthma group (Arikoglu et al. 2015).However, Alyasin et al. (2011) reported that high 25-hydroxy vitamin D levels were associated with elevated asthma immunological and inflammatory markers (Alyasin et al. 2011). Vitamin D less than $10 \mathrm{ng} / \mathrm{ml}$ was reported to be an asthma risk factor (Arikoglu et al. 2015); in our work, no significant difference was found between the three groups regarding percentage having vitamin D less than $10 \mathrm{ng} / \mathrm{ml}$.

The exact role of vitamin $\mathrm{D}$ in asthma pathogenesis is still unclear and further assessments may be needed. Vitamin D plays critical roles in the support of the immune system (which may help to prevent acute asthma exacerbations), decreasing inflammation (which may reduce acute asthma symptomology), reducing remodeling (which can reduce chronic lung dysfunction), and enhancing glucocorticoid function (which may allow reduction of administered steroids doses (Iqbal and Freishtat 2011).

One of the suggested mechanisms of vitamin D in asthma pathogenesis is the reduction in cathelicidin production and increase risk to infection. Cathelicidin is a multifunctional host defense molecule essential for normal immune responses to infections. It has many immunomodulatory properties, as inhibition of neutrophil apoptosis, chemoattractant function, cytokine release, and tissue regeneration (Yeung et al. 2011). This peptide is a part of the innate immunity and it is secreted by peripheral blood immune cells respiratory epithelial cells and regulated by vitamin D (Iqbal and Freishtat 2011). Cathelicidin expression could be inducible or constitutive by microbial, developmental, and inflammatory stimulations. However, the molecular mechanisms of gene regulation are still not clearly known (Ewa et al. 2012). Cathelicidin level was higher in our normal children compared to those in remission, but statistically not significant. Despite low levels of vitamin D in all studied groups, serum cathelicidin levels were significantly higher in the infection-induced exacerbation group compared to remission ones. Also, there was no significant correlation between vitamin D and cathelicidin in all studied groups that did not support the hypothesis that vitamin $\mathrm{D}$ deficiency can increase the frequency of infection-induced asthma attacks by reducing cathelicidin production (knowing that $1,25(\mathrm{OH}) \mathrm{D}$ is the trigger for activation of cathelicidin and not $25(\mathrm{OH}) \mathrm{D}$ which was assessed in our work as the latter is the form that reflect status of vitamin $\mathrm{D}$ in the body (Holick 2009): Randomized controlled trials found some weak evidence to support the role of vitamin D supplementation in the reduction of asthma exacerbations (Riverin et al. 2015). High levels of serum cathelicidin in our exacerbation group may reflect activation of the immune system in acute attacks of asthma independent of vitamin D levels. Many studies recorded that cathelicidin can be considered as a strong marker for a systemic immune response in bacterial or viral infections (Zhang et al. 2012; Chalmers et al. 2013). Our study goes parallel with Tugba et al. (Arikoglu et al. 2015), who reported that the serum cathelicidin levels were significantly higher in the attack group than in the controlled asthma group. On the opposite side, a low level of cathelicidin was found to be due to vitamin $\mathrm{D}$ deficiency that may predispose to infectious complications in healthy children as well as asthmatic children (Bozzetto et al. 2012; Hart et al. 2011; Hewison 2010).

In different studies, the correlation between PFT and vitamin D had many controversies. In our work, there was no correlation found between vitamin D level and pulmonary function indices apart from positive correlations with PEFR. Lack of correlations goes parallel with 
many studies (Arikoglu et al. 2015; Boonpiyathad et al. 2016), who reported that there was no observed association between serum vitamin $\mathrm{D}$ levels and lung function. A significant association between 25-OHD levels and PEFR were detected in the cross-sectional analyses in women and men (Van Schoor et al. 2012). PEFR was found to be a marker for improvement post-vitamin D administration in the deficient group (Najmuddin and Lahiri 2017; Yadav and Mittal 2014). Yao et al. 2014 (Yao et al. 2014) found a significant relationship between low serum vitamin $\mathrm{D}$ levels and impaired lung functions. Serum 25(OH)D level less than $50 \mathrm{nmol} / \mathrm{L}$ was recorded to be significantly associated with a lower FEV1/FVC (Larose et al. 2015).

It was reported that there is a significant positive correlation between body mass index (BMI) and serum levels of cathelicidin in all asthmatic patients (Arikoglu et al. 2015). Other showed that expression of cathelicidin m-RNA was significantly positively correlated with body mass index (BMI) that may be caused by the proinflammatory cytokines produced by adipose tissue, e.g., leptin that may stimulate the cathelicidin production (Benachour et al. 2009). In contrast to this result, our study showed no correlation between BMI and serum cathelicidin.

\section{Conclusion}

Vitamin D deficiency was common in asthmatic patients but was not the leading cause of infection-induced asthma exacerbations. Cathelicidin elevation in asthma exacerbations seems to be independent of vitamin D.

\section{Recommendation}

Further study on a larger number of patients and controls is needed to prove our results.

\section{Limitation of a study}

Lack of a group of non-asthmatic control during their infection for comparison with asthma exacerbation group may add a different data.

\section{Acknowledgements}

We acknowledge National Research Centre that funded this work.

\section{Funding}

This study was funded by National Research Centre as part of a project ID P100532.

\section{Availability of data and materials}

All the data of patients are available.

\section{Authors' contributions}

This work was carried out in collaboration between all authors. Authors AAM and AMAA-A designed the study and wrote the protocol. Authors AAM, $\mathrm{HMH}$, and AMAA-A managed the literature searches. All pediatric team managed the patient's recruitment and pulmonary function. Authors MAMA and RNY did the lab assessment. Author HMH performed the statistical analysis. Authors AAM and $\mathrm{HMH}$ wrote the first draft of the manuscript.
Author AMAA-A revised and edited the manuscript. Authors AAM, $\mathrm{HMH}$, and AMAA-A managed the analyses of the study and executed the manuscript in its final form. All authors read and approved the final manuscript.

\section{Ethics approval and consent to participate}

Informed consent was obtained from the parents and/or caregivers of all participants before the procedure, according to the guidelines of the ethical committee of the National Research Centre and Ain Shams University.

\section{Consent for publication}

I am and all authors have approved the manuscript for submission to your journal hoping that it is going to be accepted for publication.

\section{Competing interests}

The authors declare that they have no competing interests.

\section{Publisher's Note}

Springer Nature remains neutral with regard to jurisdictional claims in published maps and institutional affiliations.

\section{Author details}

${ }^{1}$ Pediatric Department, National Research Centre, Cairo, Egypt. ${ }^{2}$ Pediatric Department, Faculty of Medicine, Cairo University, Cairo, Egypt. ${ }^{3} \mathrm{Clinical}$ and Chemical Pathology Department, National Research Centre, Cairo, Egypt.

Received: 28 June 2018 Accepted: 13 February 2019

Published online: 04 March 2019

\section{References}

Adams JS, Hewison M (2008) Unexpected actions of vitamin D: new perspectives on the regulation of innate and adaptive immunity. Nat Clin Pract Endocrinol Metab 4:80-90 [CrossRef][Medline]

Alyasin S, Momen T, Kashef S, Alipour A (2011) The relationship between serum 25 hydroxy vitamin D levels and asthma in children. Allergy, Asthma Immunol Res 3:251-255

Arikoglu T, Kuyucu S, Karaismailoglu E, Batmaz SB, Balci S (2015) The association of vitamin D, cathelicidin, and vitamin D binding protein with acute asthma attacks in children. Allergy Asthma Proc 36(4):51-58

Benachour H, Zaiou M, Samara A et al (2009) Association of human cathelicidin (hCAP-18/LL-37) gene expression with cardiovascular disease risk factors. Nutr Metab Cardiovasc Dis 19:720-728

Bener A, Ehlayel MS, Tulic MK, Hamid Q (2012) Vitamin D deficiency as a strong predictor of asthma in children. Int Arch Allergy Immunol 157(2):168-175

Boonpiyathad T, Chantveerawong T, Pradubpongsa P, Sangasapaviliya A (2016) Serum vitamin D levels and vitamin D supplement in adult patients with asthma exacerbation. J Allergy (Cairo) 2016:4070635 Published online 2016 Nov

Bozzetto S, Carraro S, Giardano G et al (2012) Asthma, allergy and respiratory infections: the vitamin D hypothesis. Allergy. 67:10-17

Braman SS (2006) The global burden of asthma. Chest 130:4S-12S

Brehm JM, Celedo'n JC, Soto-Quiros ME, Avila L, Hunninghake GM, Forno E et al (2009) Serum vitamin D levels and markers of severity of childhood asthma in Costa Rica. Am J Respir Crit Care Med 179:765-771

Chalmers JD, McHugh BJ, Docherty C et al (2013) Vitamin-D deficiency is associated with chronic bacterial colonisation anddisease severity in bronchiectasis. Thorax 68:39-47

Comberaiti P, Tsabouri S, Piacentini GL, Moser S, Minniti F, Peroni DG (2014) Is vitamin D deficiency correlated with childhood wheezing and asthma. Front Biosci 6:31-39

El-Menem MTA, AlAziz MMA, El Guindy WM, El Banna NA (2013) The frequency of vitamin D deficiency among asthmatic Egyptian children. Egypt J Pediatr Allergy Immunol 11(2):69-73

Ewa K, Lisowski P, Jarczak J, Strzałkowska N, Jozwik A, Horbanczuk J, Krzyzewski J, Zwierzchowski L, Bagnicka E (2012) Cathelicidins: family of antimicrobial peptides. A review. Mol Biol Rep 39:10957-10970

FAO/WHO Expert Consultation. Vitamin and mineral requirements in humannutrition. http://whqlibdoc.who.int/publications/2004/9241546123.pdf

Freishtat RJ, Iqbal SF, Pillai DK, Klein CJ, Ryan LM, Benton AS, Teach SJ (2010) High prevalence of vitamin D deficiency among inner-city African American youth with asthma in Washington, DC. J Pediatr 156:948-952 
Global Strategy for Asthma Management and Prevention. Globall' nitiative for Asthma (GINA) 2011

Hamed HM, Yamamah GAN, Ibrahim NAE-A, Elhelaly NEM, Awadalla E, Shahat MM (2016) Assessment of vitamin D and iron levels in childhood asthma. Int J Pharm Clin Res 8(10):1407-1413

Harinarayan CV, Ramalakshmi T, Prasad UV, Sudhakar D (2008) Vitamin D status in Andhra Pradesh: a population based study. Indian J Med Res 127(3):211-218

Hart PH, Gorman S, Finlay-Jones JJ (2011) Modulation of the immune system by UV radiation: more than just the effects of vitamin D? Nat Rev Immunol 11: $584-596$

Hewison M (2010) Vitamin D and the immune system: new perspectives on an old theme. Endocrinol Metab Clin N Am 39:365-379

Holick MF (2007) Vitamin D deficiency. N Engl J Med 357:266-281

Holick MF (2009) Vitamin D status: measurement, interpretation and clinical application. Ann Epidemiol 19:73-78

Iqbal SF, Freishtat RJ (2011) The mechanism of action of Vitamin D in the asthmatic lung. J Investig Med 59(8):1200-1202

Jirapongsananuruk O, Melamed I, Leung DY (2000) Additive immunosuppressive effects of 1, 25-dihydromunol D3 and corticosteroids on TH1, but not TH2, responses. J Allergy Clin Immunol 106:981-985 [CrossRef][Medline]

Kolokotroni O, Anna P, Nicos M, Christiana K, Vasilios R, Polyxeni N, Panayiotis KY (2015) Vitamin D levels and status amongst asthmatic and non-asthmatic adolescents in Cyprus: a comparative cross-sectional study. BMC Public Health 15:1-9

Larose TL, Langhammer A, Chen Y et al (2015) Serum 25-hydroxyvitamin D levels and lung function in adults with asthma: the HUNT study. Eur Respir J 45: 1019-1026

Litonjua AA, Weiss ST (2007) Is vitamin D deficiency to blame for the asthma epidemic? J Allergy Clin Immunol 120:1031-1035

Mak G, Hanania NA (2011) Vitamin D and asthma. Curr Opin Pulm Med 17:1-5

Miraglia del Giudice M, Allegorico A (2016) The role of Vitamin D in allergic diseases in children. J Clin Gastroenterol 50(suppl 2):133S-135S

Najmuddin F, Lahiri K (2017) Vitamin D in pediatric asthma and allergic rhinitis: benefits beyond skeletal health. J Clin Immunolo Allergy 3(1):1

Paul G, Brehm JM, Alcorn JF, Holguín F, Aujla SJ, Celedón JC (2012) Vitamin D and asthma. Am J Respir Crit Care Med 185(15):124-132

Prentice A (2008) Vitamin D deficiency: a global perspective. Nutr Rev 66(Suppl 2):S153-SS64

Riverin BD, Maguire JL, Li P, Vitamin D (2015) Supplementation for childhood asthma: a systematic review and meta-analysis. PLoS One 10(8):e0136841

Soheila A, Tooba M, Sara K, Abbass A, Reza A (2011) The relationship between serum 25 hydroxy vitamin D levels and asthma in children. Allergy, Asthma Immunol Res 3(4):251-255

Urry Z, Xystrakis E, Richards DF, McDonald J, Sattar Z, Cousins DJ, Corrigan CJ, Hickman E, Brown Z, Hawrylowicz CM (2009) Ligation of TLR9 induced on human IL-10-secreting Tregs by 1,25-dihydroxyvitamin D3 abrogates regulatory function. J Clin Invest 119:387-398 [Medline]

Uysalol M, Mutlu LC, Saracoglu GV (2013) Childhood asthma and vitamin D deficiency in Turkey: is there cause and effect relationship between them? Ital J Pediatr 39:78

Van Schoor NM, de Jongh RT, Daniels JM, Heymans MW, Deeg DJ, Lips P (2012) Peak expiratory flow rate shows a gender-specific association with vitamin $D$ deficiency. J Clin Endocrinol Metab 97(6):2164-2171.https://doi.org/10.1210/ jc.2011-3199 Epub 2012.Apr 3

White JH (2010) Vitamin D as an inducer of cathelicidin antimicrobial peptide expression: past, present and future. J Steroid Biochem Mol Biol 121:234-238. https://doi.org/10.1016/j.jsbmb.2010.03.034

Yadav M, Mittal K (2014) Effect of vitamin D supplementation on moderate to severe bronchial asthma. Indian J Pediatr 81:650-654

Yao TC, Tu YL, Chang SW et al (2014) Serum 25-hydroxyvitamin D levels in relation to lung function and exhaled nitric oxide in children. J Pediatr 165: 1098-1103

Yeung AT, Gellatly SL, Hancock RE (2011) Multifunctional cationic host defence peptides and their clinical applications. Cell Mol Life Sci 68:2161-2176

Zhang C, Zhao L, Ma L et al (2012) Vitamin D status and expression of vitamin D receptor and LL-37 in patients with spontaneous bacterial peritonitis. Dig Dis Sci 57:182-188

\section{Submit your manuscript to a SpringerOpen ${ }^{\circ}$ journal and benefit from:}

- Convenient online submission

- Rigorous peer review

- Open access: articles freely available online

- High visibility within the field

- Retaining the copyright to your article

Submit your next manuscript at $\boldsymbol{\nabla}$ springeropen.com 